\title{
Removal of elemental mercury and divalent mercury with ammonium \\ sulfide in smelting gas containing $\mathrm{SO}_{2}$
}

\author{
Xueqian Wang ${ }^{1, a,{ }^{*}}$, Jianlin Xiong ${ }^{2, b}$, Langlang Wang ${ }^{3, \mathrm{c}}$ and Shudi Yan ${ }^{4, \mathrm{~d}}$ \\ 1, 2, 3and 4 Faculty of Environmental Science and Engineering, Kunming University of Science and \\ Technology, Kunming 650500, Yunnan, China. \\ awwqb214@163.com, b2893971474@qq.com, 512229466@qq.com, d173514656@qq.com
}

Keywords: $\left(\mathrm{NH}_{4}\right)_{2} \mathrm{~S}$, simultaneous removal, $\mathrm{Hg}^{0}, \mathrm{Hg}^{2+}, \mathrm{SO}_{2}$

Abstract. A set of simulation equipment is set up after the conditions of removing $\mathrm{SO}_{2}$ and heavy metal $\mathrm{Hg}\left(\mathrm{Hg}^{0}\right.$ and $\left.\mathrm{Hg}^{2+}\right)$ has been investigated, the results of the removal technology method of absorption $\mathrm{Hg}^{0}, \mathrm{Hg}^{2+}$ in smelting gases containing $\mathrm{SO}_{2}$ with $\left(\mathrm{NH}_{4}\right)_{2} \mathrm{~S}$ is tested, and their composition of reaction products and sediment are analyzed with XRD and XPS. Obtained that: when absorption concentration of $\left(\mathrm{NH}_{4}\right)_{2} \mathrm{~S}$ are $0.8 \mathrm{~mol} / \mathrm{L}$, in $\mathrm{pH} 7.0-3.0$ removal efficiency of $\mathrm{Hg}^{0}$ and $\mathrm{SO}_{2}$ is higher, temperature will affect the absorption of $\mathrm{Hg}^{0}$, when reaction temperature is $30^{\circ} \mathrm{C}$ the absorption of $\mathrm{Hg}^{0}$ can be achieved the best. Under these optimum conditions, the removal efficiency of $\mathrm{Hg}^{0} \mathrm{Hg}^{2+}$ and $\mathrm{SO}_{2}$ could reach $89.45 \%, 99.42 \%$ and over $99.99 \%$, the participation of $\mathrm{SO}_{2}$ has a promote consequence on removal of $\mathrm{Hg}^{0}$. The main reaction product is $\mathrm{HgS}, \mathrm{HgSO}_{4}$, $\left(\mathrm{NH}_{4}\right)_{2} \mathrm{~S}_{2} \mathrm{O}_{3}$.

\section{Introduction}

Non-ferrous smelting process would produce a large amount of flue gas, which main composition of smelting fumes are $\mathrm{SO}_{2}, \mathrm{SO}_{3}, \mathrm{H}_{2} \mathrm{O}$ and heavy metals. Among them, Mercury is one of the most toxic heavy metals. In China, zinc smelting atmospheric mercury emissions reach to 49.1t, mercury emissions of $\mathrm{Hg}^{0}, \mathrm{Hg}^{2+}$ and $\mathrm{Hg}^{\mathrm{p}}$ is $78 \%, 17 \%$ and $5 \%$ of total mercury emissions respectively recent years. $\mathrm{Hg}^{0}$ has gradually become a leading concern due to its high toxicity, it possesses high volatility and low solubility in water, and it is easily spread for a long time and long distances in the atmosphere. [1] The concentration of $\mathrm{SO}_{2}$ is about $0.05 \%$ to $25 \%$ and $\mathrm{SO}_{2}$ emissions constitute more than 8 percent of China's total $\mathrm{SO}_{2}$ emissions [2].

For processing heavy metals from the flue gases, most research in internal and abroad, mainly by adsorption $[3,4,5,6]$ and catalytic oxidation method $[7,8,9]$. But most of them either have a high economical cost or some of them have the problem of secondary pollution. Thus the developing of low costs and low pollution technology for mercury removal is still necessary. For the treatment of $\mathrm{SO}_{2}$ smelting gas, there are related research in internal and abroad. This experiment chooses $\left(\mathrm{NH}_{4}\right)_{2} \mathrm{~S}$ as absorbing liquid for the removal of $\mathrm{SO}_{2}$, and it also has a relatively high absorption rate for $\mathrm{Hg}^{2+}$ and $\mathrm{Hg}^{0}$. This paper focuses on the study of removal of bivalent mercury $\left(\mathrm{Hg}^{2+}\right)$, elemental mercury $\left(\mathrm{Hg}^{0}\right)$ and in simulated flue gas containing $\mathrm{SO}_{2}$ by $\left(\mathrm{NH}_{4}\right)_{2} \mathrm{~S}$ solution.

\section{Experimental}

\section{Materials and methods}

The experimental device for using ammonium sulfide to remove $\mathrm{Hg}^{0}, \mathrm{Hg}^{2+}$ and $\mathrm{SO}_{2}$ in simulated 
flue gas is shown in Fig.1. In this experimental, $\mathrm{Hg}^{0}, \mathrm{Hg}^{2+}$ simulated flue gas was the mixed with $\mathrm{SO}_{2}$ of single $\mathrm{Hg}^{0}$ and $\mathrm{Hg}^{2+}$. The corresponding tail gas absorption solution of $\mathrm{Hg}$ was acidic solution of $\mathrm{KMnO}_{4}$, and the corresponding tail gas absorption solution of $\mathrm{SO}_{2}$ was $5 \% \mathrm{NaOH}$. Because $\mathrm{Hg}^{0}$ is easy to volatilize, $\mathrm{u}$-shaped tube is used for generation of $\mathrm{Hg}^{0}$. Dried compressed air is used to access into mercury vapor tube (Accounting for the total amount of oxygen is about 21\%), flow rate is $10 \sim 20 \mathrm{~mL} / \mathrm{min}$, inlet the mix bottle to mixed with $\mathrm{SO}_{2}$. And for $\mathrm{Hg}^{2+}$, put the soiled-state mercuric chloride $\left(\mathrm{HgCl}_{2}\right)$ into a tubular resistance furnace (SLG1200-60, 220V, 4000W), then heated tubular resistance furnace to $400^{\circ} \mathrm{C}$, then carrier gases were the mixture of nitrogen and sulfur dioxide with a constant flow rate of $200 \mathrm{~mL} / \mathrm{min}$. inlet concentration of $\mathrm{Hg}^{0}$ is maintained at 20 40 mg $/ \mathrm{m}^{3}$, inlet concentration of $\mathrm{Hg}^{2+}$ is $10 \sim 30 \mathrm{mg} / \mathrm{m}^{3}$, which is correspond concentration of $\mathrm{Hg}^{0}$ in smelting gases.

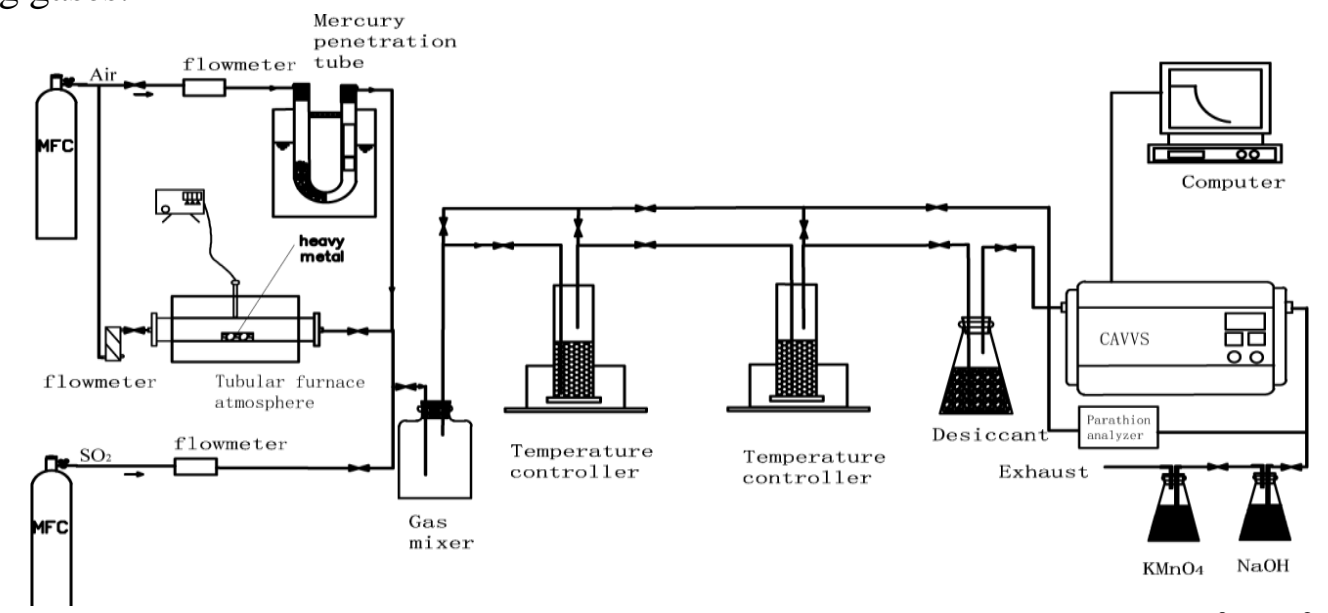

Fig.1 Simultaneously removal experimental device of absorbing smelting gas $\mathrm{Hg}^{0}, \mathrm{Hg}^{2+}$ and $\mathrm{SO}_{2}$ with $\left(\mathrm{NH}_{4}\right)_{2} \mathrm{~S}$.

\section{The experimental principle}

The principle of $\mathrm{Hg}^{2+}$ removal can be fully explained by the equation ((Eq.1), Mercury ions $\left(\mathrm{Hg}^{2+}\right)$ reacted with sulfide ions $\left(\mathrm{S}^{2-}\right)$ to generate stable mercuric sulfide precipitate under the condition of weak alkaline, [10]. And as shown in (Eq.2-3), because of the existence of $\mathrm{SO}_{2}$ in simulated flue gas react with the solution, and the reaction product between sulfur dioxide and ammonium sulfide, hydrogen sulfide $\left(\mathrm{H}_{2} \mathrm{~S}\right)$ and sulfur $(\mathrm{S})$, can react with mercury $\left(\mathrm{Hg}^{0}\right)$, the principle of $\mathrm{Hg}^{0} \mathrm{removal}$ was shown in ((Eq.4-5).

Principle of $\left(\mathrm{NH}_{4}\right)_{2} \mathrm{~S}$ absorb $\mathrm{SO}_{2}$ : According produces $\mathrm{H}_{2} \mathrm{~S}$ and no $\mathrm{H}_{2} \mathrm{~S}$, the absorption process into $\mathrm{pH}>7$ stages and $\mathrm{pH}<$ Stage 7 . And the overall reaction chemical equation is shown in Eq.2-3.

$$
\begin{aligned}
& \mathrm{Hg}^{2+}+\mathrm{S}^{2-} \rightarrow \mathrm{HgS} \downarrow \\
& 6 \mathrm{SO}_{2}+4\left(\mathrm{NH}_{4}\right)_{2} \mathrm{~S}+4 \mathrm{H}_{2} \mathrm{O}+\mathrm{O}_{2} \rightarrow 2\left(\mathrm{NH}_{4}\right)_{2} \mathrm{~S}_{2} \mathrm{O}_{3}+4 \mathrm{NH}_{4} \mathrm{HSO}_{4}+2 \mathrm{H}_{2} \mathrm{~S} \\
& \left(\mathrm{NH}_{4}\right)_{2} \mathrm{~S}_{2} \mathrm{O}_{3}+2\left(\mathrm{NH}_{4}\right) \mathrm{HSO}_{3} \rightarrow 2 \mathrm{~S}+2\left(\mathrm{NH}_{4}\right) \mathrm{SO}_{4}+2 \mathrm{H}_{2} \mathrm{O} \\
& \mathrm{Hg}^{0}+\mathrm{S} \rightarrow \mathrm{HgS} \downarrow \\
& \mathrm{Hg}^{0}+\mathrm{H}_{2} \mathrm{~S} \rightarrow \mathrm{HgS} \downarrow+\mathrm{H}_{2}
\end{aligned}
$$




\section{Results and discussion}

\section{Effect of $\left(\mathrm{NH}_{4}\right)_{2} \mathrm{~S}$ absorption concentration on removal efficiency}

Adding $\left(\mathrm{NH}_{4}\right)_{2} \mathrm{~S} 100 \mathrm{~mL}$ which concentration is $0,0.2,0.4,0.8$ and $1.0 \mathrm{~mol} / \mathrm{L}$ respectively in absorption bottles, removal efficiency of $\mathrm{Hg}^{0}, \mathrm{Hg}^{2+}$ and $\mathrm{SO}_{2}$ are affected with concentration of $\left(\mathrm{NH}_{4}\right)_{2} \mathrm{~S}$, the test results are shown in Fig.2. As can be seen from the Fig.2, when the concentration of $\left(\mathrm{NH}_{4}\right)_{2} \mathrm{~S}$ solution was increased from 0 to $0.2 \mathrm{~mol} / \mathrm{L}$, the removal efficiency of $\mathrm{Hg}^{0}$ also increased from $50.89 \%$ to $67.40 \%$, removal efficiency of $\mathrm{Hg}^{2+}$ increased from $82.64 \%$ to $95.06 \%$ respectively, and the removal efficiency of $\mathrm{SO}_{2}$ also increased from $88.7 \%$ to $98.8 \%$. When the concentration of $\left(\mathrm{NH}_{4}\right)_{2} \mathrm{~S}$ solution increased from 0.2 to $1.0 \mathrm{~mol}$, the removal efficiencies of $\mathrm{Hg}^{0}$, $\mathrm{Hg}^{2+}$ and $\mathrm{SO}_{2}$ could reach $87.71 \%, 99.96 \%$ and $99.92 \%$ respectively. As can be seen from equations (1-5), when the concentration of $\left(\mathrm{NH}_{4}\right)_{2} \mathrm{~S}$ solution increased the concentration of $\mathrm{S}^{2-}, \mathrm{S}$ and $\mathrm{H}_{2} \mathrm{~S}$ increased too.

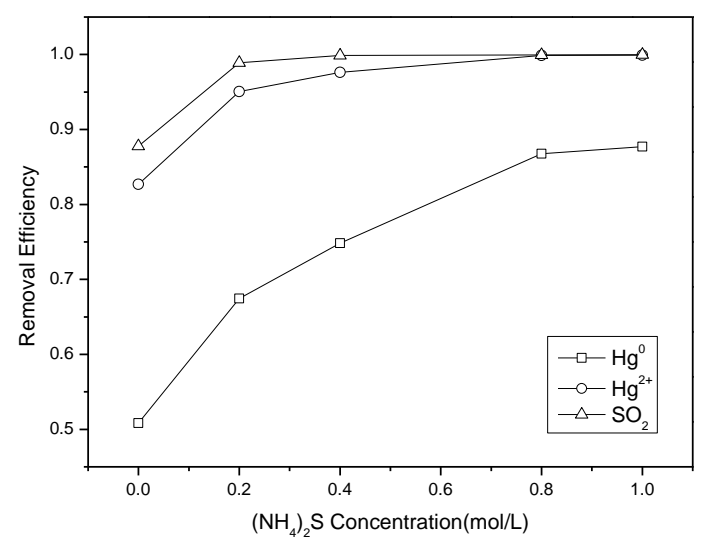

Fig.2 The influence of concentration on removal of mercury and $\mathrm{SO}_{2}$ from simulated flue gas.

(Concentration of $\mathrm{SO}_{2}$ was $6 \%$ )

\section{Effect of $\mathrm{SO}_{\mathbf{2}}$ absorption concentration on removal efficiency}

Adjusting concentration of $\mathrm{SO}_{2}$ gas to $0 \%, 2 \%, 4 \%, 6 \%, 10 \%$ respectively, removal efficiency of $\mathrm{Hg}^{0}, \mathrm{Hg}^{2+}$ and $\mathrm{SO}_{2}$ are affected with concentration of $\left(\mathrm{NH}_{4}\right)_{2} \mathrm{~S}$, the test results are shown in Fig.3. As the concentration of $\mathrm{SO}_{2}$ from simulated flue gas was increased from $0 \%$ to $2 \%$, the removal efficiencies of $\mathrm{Hg}^{2+}, \mathrm{SO}_{2}$, decreased from $99.64 \%, 100 \%$, to $99.05 \%$, 99.99\%, but the removal efficiencies of $\mathrm{Hg}^{0}$ increased from $76.46 \%$ to $80.61 \%$ (Fig.3). When the concentrations of $\mathrm{SO}_{2}$ from $2 \%$ to $10 \%$, the removal efficiencies of $\mathrm{Hg}^{0}, \mathrm{Hg}^{2+}, \mathrm{SO}_{2}$, decreased from $80.61 \%, 99.05 \%$ and $99.99 \%$ to $71.08 \%, 98.44 \%$ and $99.57 \%$. The participation of $\mathrm{SO}_{2}$ leads to $\mathrm{pH}$ of the solution is reduced, an acidic conditions more conducive to the absorption of $\mathrm{Hg}^{0}$, and $\mathrm{SO}_{2}$ react with $\left(\mathrm{NH}_{4}\right)_{2} \mathrm{~S}$ solution produces $\mathrm{S}$ and $\mathrm{H}_{2} \mathrm{~S}$ can react with $\mathrm{Hg}^{0}$. But as the reaction between $\mathrm{SO}_{2}$ and $\left(\mathrm{NH}_{4}\right)_{2} \mathrm{~S}$ proceeds are consuming solute, which makes removal efficiency of $\mathrm{Hg}^{0}, \mathrm{Hg}^{2+}$ decline. 


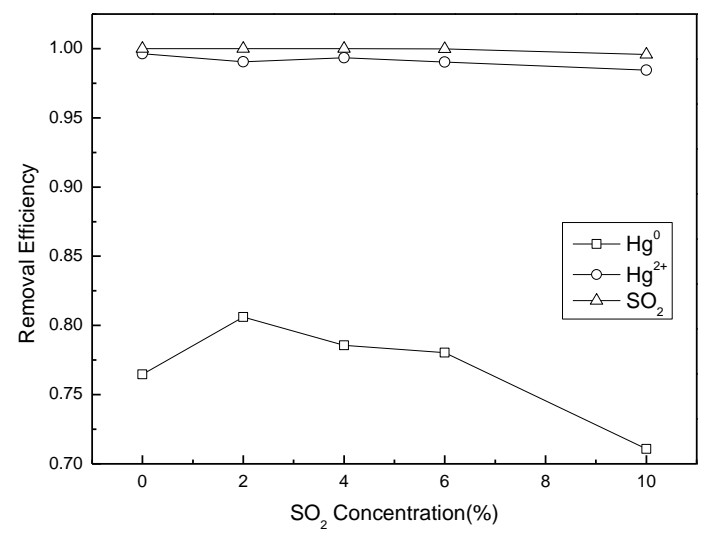

Fig.3 The influence of $\mathrm{SO}_{2}$ on removal of mercury and $\mathrm{SO}_{2}$ from simulated flue gas.

(concentration of $\left(\mathrm{NH}_{4}\right)_{2} \mathrm{~S}$ was $0.8 \mathrm{~mol} / \mathrm{L}$, temperature of $\left(\mathrm{NH}_{4}\right)_{2} \mathrm{~S}$ was $20^{\circ} \mathrm{C}$ )

\section{The influence of $\mathrm{pH}$ value on removal efficiency}

Continue experiment to be done in different $\mathrm{pH}$, and averaging $\mathrm{pH}$ is used to observe the changes of $\mathrm{pH}$ value in absorption process, results are shown in Fig.4. As can be seen from Fig.4, when $\mathrm{pH}$ is from 12 to 7 , absorption rate of $\mathrm{Hg}^{0}$ increases from $48.89 \%$ to $74.67 \%$ with $\mathrm{pH}$ decrease. Acidic base of $\mathrm{pH}<7.0$ is more beneficial to $\mathrm{Hg}^{0}$ 's absorption, but the range of removal efficiencies for $\mathrm{Hg}^{2+}$ decrease, were $99.16 \%-97.14 \%$, when the $\mathrm{pH}$ value was nearby 7 , the removal efficiencies reduced to a minimum level. When $\mathrm{pH}$ is higher than 4.0 removal efficiency of $\mathrm{SO}_{2}$ remains over 99.9\%, $\mathrm{pH}$ has little effect on the absorption of $\mathrm{SO}_{2}$. Gaseous $\mathrm{Hg}^{0}$ can be dissolved into ions easier when the solution was acidic base, but when $\mathrm{pH}$ is reduced to below 3.0, absorption rate is low to $54.95 \%$ because of the $\left(\mathrm{NH}_{4}\right)_{2} \mathrm{~S}$ solute consumption. But no matter under acidic or alkaline base, ions state of mercury $\left(\mathrm{Hg}^{2+}\right)$ can easily reacted with sulfur ions.

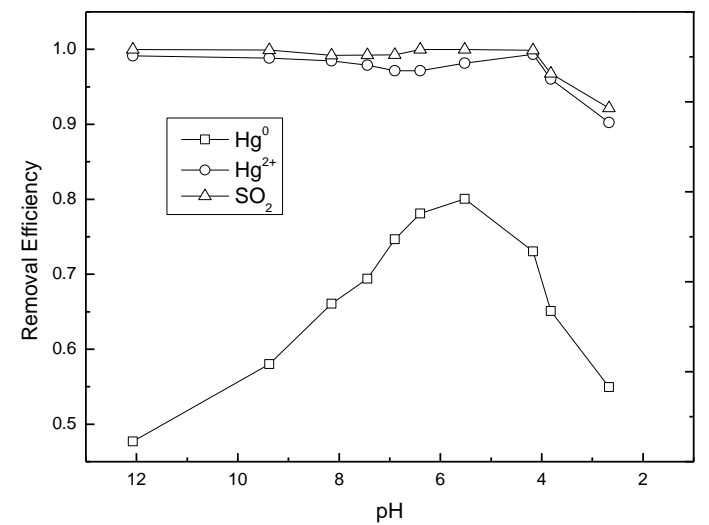

Fig.4 The influence of $\mathrm{pH}$ value on removal of mercury and $\mathrm{SO}_{2}$ from simulated flue gas.

(Concentration of $\left(\mathrm{NH}_{4}\right)_{2} \mathrm{~S}$ was $0.8 \mathrm{~mol} / \mathrm{L}$, concentration of $\mathrm{S} \mathrm{O}_{2}$ was $6 \%$, temperature of $\left(\mathrm{NH}_{4}\right)_{2} \mathrm{~S}$ was $\left.20^{\circ} \mathrm{C}\right)$ 


\section{The influence of temperature on removal efficiency}

Place $\left(\mathrm{NH}_{4}\right)_{2} \mathrm{~S} 100 \mathrm{~mL}$ which concentration is $0.8 \mathrm{~mol} / \mathrm{L}$ in absorption bottles of series two stage absorption, continue experiment in different reaction temperature $\left(20^{\circ} \mathrm{C}, 30^{\circ} \mathrm{C}, 40^{\circ} \mathrm{C}, 50^{\circ} \mathrm{C}, 70^{\circ} \mathrm{C}\right)$ respectively, results are shown in Fig.5. As can be seen from Fig.5, when the temperature increased from $20^{\circ} \mathrm{C}$ to $30^{\circ} \mathrm{C}$, removal efficiencies of $\mathrm{Hg}^{0}$ and $\mathrm{Hg}^{2+}$ both increased, reach to $89.45 \%$ and $99.42 \%$ when the temperature was increased from $30^{\circ} \mathrm{C}$ to $70^{\circ} \mathrm{C}$, the removal efficiencies of $\mathrm{Hg}^{2+}$ were not significantly increased, and the removal efficiencies of $\mathrm{Hg}^{0}$ turn to decreased to $71.43 \%$, the removal efficiencies of $\mathrm{Hg}^{2+}$, SO2 were not significantly increased. Due to a range of rise temperature due to the accelerated the molecular motion to some extent, but the removal efficiency of ascension, but for $\mathrm{Hg}^{0}$, the rise of reaction temperature will promote its volatile, leading to removal efficiency decreased.

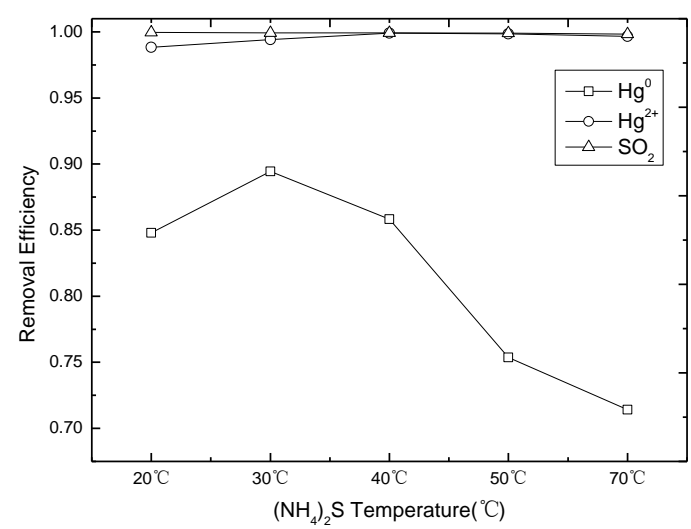

Fig.5 The influence of temperature on removal of mercury and $\mathrm{SO}_{2}$ from simulated flue gas.

(Concentration of $\left(\mathrm{NH}_{4}\right)_{2} \mathrm{~S}$ was $0.8 \mathrm{~mol} / \mathrm{L}$, concentration of $\mathrm{SO}_{2}$ was $6 \%$, initial $\mathrm{pH}$ value of $\left(\mathrm{NH}_{4}\right)_{2} \mathrm{~S}$ was 8)

\section{Characterization of materials}

\section{XRD analysis}

As shown in Fig.6 $\mathrm{HgS}$ characteristic peak is obvious that the reaction substance is the mercuric sulfide and have complete crystal shape, which proved that when solution absorb $\mathrm{Hg}^{0}$ in the presence of $\mathrm{SO}_{2}$ a small amount of black precipitates appears, and its composition is mainly $\mathrm{HgS}$, it is same as $\mathrm{Hg}^{2+}$.

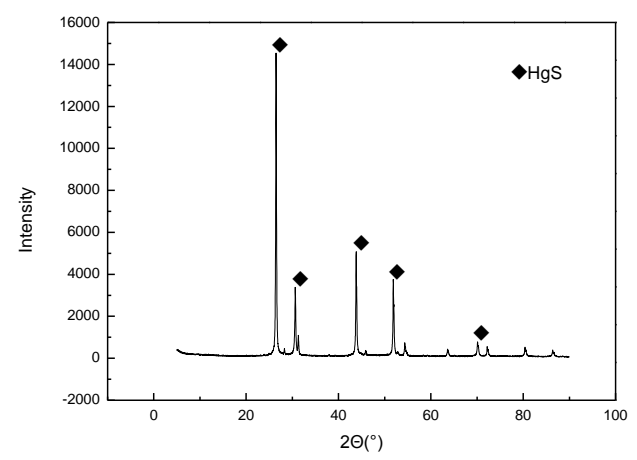

Fig.6 XRD patterns of $\left(\mathrm{NH}_{4}\right)_{2} \mathrm{~S}$ removal $\mathrm{Hg}^{0}$ generated precipitation. 


\section{XPS analysis}

In order to further determine the products of reaction, XPS analysis was used to measure the kind and composition of the absorption liquid crystal, Analysis results show that in Fig.7. major S2p peaks centers at $168.78 \mathrm{eV}$ and $168.42 \mathrm{eV}$, verify that the main form of products in solution is $\mathrm{SO}_{4}{ }^{2-}$ and $\mathrm{S}_{2} \mathrm{O}_{3}{ }^{2-}$. And the $\mathrm{S} 2 \mathrm{p} 3 / 2$ peak center 170.45 indicate the presence of $\mathrm{H}_{2} \mathrm{~S}$. [11]

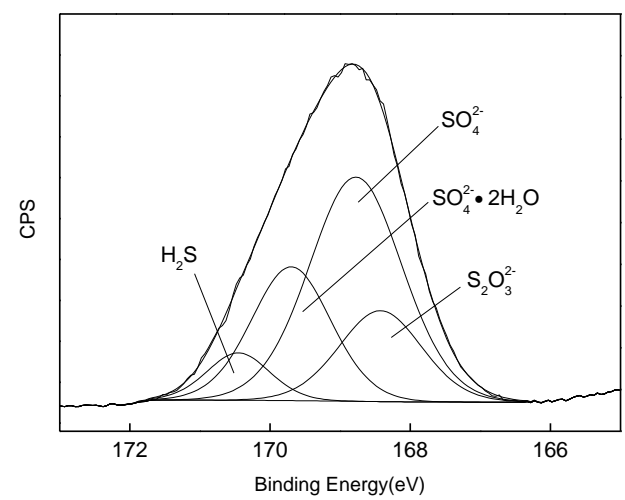

Fig.7 XPS patterns of absorbing liquid crystalline of $\left(\mathrm{NH}_{4}\right)_{2} \mathrm{~S}$ removal of $\mathrm{SO}_{2}$.

\section{Conclusion}

Considering removal efficiency and economic costs, to removal of $\mathrm{Hg}^{0}$ and $\mathrm{Hg}^{2+}$ from metallurgical off-gas contains the $\mathrm{SO}_{2}$ with $\left(\mathrm{NH}_{4}\right)_{2} \mathrm{~S}$ as the absorption liquid, the optimal concentration, $\mathrm{pH}$ value and temperature of $\left(\mathrm{NH}_{4}\right)_{2} \mathrm{~S}$ solution were $0.8 \mathrm{~mol} / \mathrm{L}, 6$ and $30^{\circ} \mathrm{C}$ respectively. Under these conditions, the removal efficiencies of $\mathrm{Hg}^{0}, \mathrm{Hg}^{2+}$ and $\mathrm{SO}_{2}$ from simulated flue gas could reach $89.45 \%, 99.42 \%, 99.99 \%$, respectively. The results of XRD and XPS shows that the mechanism of Hg's removal was mainly chemical deposition, and the participation of $\mathrm{SO}_{2}$ has a promote consequence on removal of $\mathrm{Hg}^{0}$. The main products is likely to be $\mathrm{HgS},\left(\mathrm{NH}_{4}\right)_{2} \mathrm{~S}_{2} \mathrm{O}_{3},\left(\mathrm{NH}_{4}\right)_{2} \mathrm{SO}_{4}$, and so on, it's ease of secondary use.

\section{Acknowledgments}

This work was supported by the National Natural Science Foundation of China under Grant No. 51268021, No. 51368026, U1137603.

\section{Reference}

[1 NN Wang, QR Huang, LH Feng. Study on soft measurement of $\mathrm{SO}_{2}$ Conversion ratio of producing sulfuric acid frommetallurgical off-gas based on MLR. 2013 25th Chinese Control and Decision Conference, CCDC. 2013: 3091-3094.

[2] XQ Wang, YX Ma, Y Shi, P Wang, Y Lan, XL Guo, LL Wang, P Ning. CIESC Journal. 2014; 65(9):3661-3668.

[3] X Cui, LP Ma, CL Deng, WJ Xu, Y Mao. Chemical Industry and Engineering Progress. 2011;30:1607-1613.

[4] Diaz-Somoano M, Mart inez-Tarazona MR. Fuel. 2005;84:717-721.

[5] Thomas Klasson K, Lima IM. F Journal of Environmental Management. 2010;91: 2466-2470.

[6] F Jiao, Y Cheng, L Zhang. Proceedings of the Combustion Institute. 2011; 33: 2787-2793.

[7] Wendt J, Lee SJ. Fuel. 2010; 89 :894-903. 
[8] XF Yang, ZG Shen. Chemosphere. 2013; 90: 653-656.

[9] H Zhang, JT Zhao, YT Fang, Y Wang. Journal of Fuel Chemistry and Technology. 2011; 39: 373-377

[10] HY Lin, CS Yuan, CH Wu, CH Hung. Journal of Air Waste Manage. Association. 2006; 56: 1558-1566.

[11] Information on http://srdata.nist.gov/xps/selEnergyType.aspx 